\title{
Proteocephalid cestode infection in tucunaré Cichla sp. (Osteichthyes: Cichlidae) from Paraná River, São Paulo
}

[Infecção por cestóides proteocefalídeos em tucunaré Cichla sp. (Osteichthyes: Cichlidae), no Rio Paraná, São Paulo]

R.S. Santos ${ }^{1}$, K. Roumbedakis ${ }^{2}$, N.G. Marengoni ${ }^{3}$, H.K. Takahashi ${ }^{1}$, F.D.A. Pimenta ${ }^{1}$, C.M.R. Melo $^{4}$, M.L. Martins ${ }^{2 *}$

${ }^{1}$ Centro de Aquicultura - Universidade do Oeste Paulista-UNOESTE - Presidente Prudente, SP ${ }^{2}$ Departamento de Aquicultura - CCA - Universidade Federal de Santa Catarina Rod. SC 404, km 3 88040-900 - Florianópolis, SC

${ }^{3}$ Centro de Ciências Agrárias - Universidade Estadual Oeste do Paraná-UNIOESTE - Marechal Cândido Rondon, PR

${ }^{4}$ Laboratório de Moluscos Marinhos - Departamento de Aquicultura -CCA - UFSC - Florianópolis, SC

\begin{abstract}
The occurrence of proteocephalid cestodes in tucunaré Cichla sp., captured monthly, between August 2000 and August 2001, in Paraná River, Presidente Epitácio, SP, was evaluated. From 128 specimens, 71 (55.6\%) were parasitized by Proteocephalus macrophallus (Diesing, 1850) and/or P. microscopicus (Woodland, 1935). Total mean abundance and intensity were 157.08 and 223.41, respectively. The highest prevalence $(90 \%)$ mean abundance $(1,122.4)$ and intensity indexes $(1,247.11)$ occurred in February 2001, while in September 2000 there were no observed animals infected by cestodes. No relationship between the sex of the host and parasitological indexes was found.
\end{abstract}

Keywords: fish, tucunare, parasitism, Proteocephalidae, Paraná River

\section{RESUMO}

Avaliou-se a ocorrência de cestóides proteocefalídeos em tucunaré Cichla sp., capturados mensalmente, entre agosto de 2000 e agosto de 2001, no rio Paraná, em Presidente Epitácio, SP. Um total de 128 espécimes foram analisados, dos quais 71 (55,6\%) estavam parasitados por Proteocephalus macrophallus (Diesing, 1850) e/ou P. microscopicus (Woodland, 1935). A abundância e intensidade média total foram de 157,08 e 223,41, respectivamente. A maior prevalência (90\%), juntamente com os maiores índices de abundância $(1122,4)$ e intensidade média $(1247,11)$ ocorreram no mês de fevereiro 2001 , enquanto no mês de setembro 2000 não foram observados animais parasitados por cestóides. Não houve relação entre o sexo do hospedeiro e os índices parasitológicos.

Palavras-chave: peixe, tucunaré, parasitismo Proteocephalidae, rio Paraná

\section{INTRODUCTION}

Tucunare, Cichla sp., is a typical piscivorous cichlid fish native from the Amazon basin, and of great importance as commercial fish and sport (Gomiero and Braga, 2003). It was introduced into the lakes of many tropical and subtropical regions, including Brazil, Panama, Puerto Rico and Hawaii and Florida in USA (Jepsen et al.,

Recebido em 12 de março de 2010

Aceito em 14 de abril de 2011

*Autor para correspondência (corresponding author)

E-mail: mlaterca@cca.ufsc.br
1997). In Brazil, it was introduced in the hydrographic basins such as the ParanáParaguay, São Francisco and others in northeastern Brazil (Gomiero and Braga, 2004a) and showed rapid adaptation in the hydroelectric reservoirs (Gomiero and Braga, 2004b).

Stable environments are more susceptible to the introduction of new species, especially piscivorous, than those unstable ones (Zaret, 
1982). Introduced species affect native species through competition for available resources, predation, pathogen transfer, or simply by habitat alteration (Gomiero and Braga, 2004a). The negative results of introduced non-native species on the parasite populations are not known, and it is frequently blamed for severe damage, especially for native populations (Gomiero and Braga, 2004a).

According to Rego (2004), 120 cestode species belong to 6 orders in the neotropics. Ninety percent belong to Proteocephalidae and are found in teleosts. Proteocephalids are the most numerous and important helminthes in freshwater fish, having been described approximately 80 species in freshwater fishes from South America, mostly found in siluriform fish (Rego et al., 1999).

This group of parasites has been studied in several fish species from the Paraná River: Paulicea luetkeni (de Chambrier et al., 1999); Parauchenipterus galeatus (Pavanelli and Santos, 1991); Pseudoplatystoma corruscans (de Chambrier et al., 2006); Sorubim lima (Pavanelli and Takemoto, 2000; de Chambrier, 2003); Cichla monoculus (Machado et al. 2000); Cichla piquiti (Martins et al., 2009); Parauchenipterus galeatus (Pavanelli and Santos, 1990) and other teleost fish (Rego et al., 1998, 1999).

The sex of the hosts is an important factor that influences the fish parasite composition and may be related to behavior, biological and physiological differences between male and female specimens (Machado et al., 1994; Takemoto and Pavanelli, 1996). Changes in diet and feeding habitats of the hosts can also influence their parasitic fauna (Dogiel, 1970).

The objective of this work was to study the proteocephalid parasitological occurrence in Cichla sp. in the Paraná River, SP and the influence of sex on the parasitism.

\section{MATERIAL AND METHODS}

A total of 128 fish were collected in Paraná River, Presidente Epitácio, SP, between August 2000 and August 2001, being 10 fish per month, except in August 2000, when only 8 fish were collected. The rainfall and water quality data such as $\mathrm{pH}$, turbidity, temperature, dissolved oxygen, conductivity and alkalinity were performed in each collection, except in January 2001.

Fish were anesthetized, the sex identified and then submitted to parasitological examination. The cestodes found in the gut were isolated and fixed in hot $4 \%$ formaldehyde solution and stored in ethanol 75\%. The helminthes were stained with Mayer hydrochloric carmine (modified from Langeron, 1949), differentiated in acid ethanol, dehydrated through a gradual ethanol series, cleared with Eugenol or beech wood creosote and mounted as Canada balsam. Thick cross hand-cutting sections of the proglottides were stained following the same procedure; fragments of the strobila were embedded in paraffin wax, transversely sectioned at $13-19 \mu \mathrm{m}$, stained with Weigert's hematoxylin and counterstained with $1 \%$ eosin B and mounted in Canada balsam (de Chambrier and Pertierra, 2002).

The prevalence, mean intensity and mean abundance were calculated according to Bush et al. (1997). For comparison of mean abundance and intensity among the months, data was transformed into $\log 10$ and $\log 10(n+1)$, respectively, and subjected to ANOVA and subsequently by Student's t test $(\mathrm{P}<0.05)$ using adjustment for multiple testes by Bonferroni adjust. The existence of a relationship between the sex of the host and parasitological index was verified.

Specimens of Proteocephalus macrophallus (Diesing, 1850) Scholz, de Chambrier, Prouza and Royero 1996 and Proteocephalus microscopicus (Woodland, 1935) have been deposited at the Natural History Museum, Geneva, Switzerland (respectively MHNG Collection number INVE 34677, 35401, 35402 and INVE 34065, 35403) and at the Helminthological Collection of Instituto Oswaldo Cruz (CHIOC), number 36845a-b ( $P$. macrophallus) and 36846a-b (P. microscopicus).

\section{RESULTS}

The highest temperatures were observed in May $2001 \quad\left(28.8^{\circ} \mathrm{C}\right)$, November $2000 \quad\left(28.7^{\circ} \mathrm{C}\right)$, February $\left(28.4^{\circ} \mathrm{C}\right)$ and March $2001\left(28.2^{\circ} \mathrm{C}\right)$, while the lowest were found in August 2001 $\left(22.0^{\circ} \mathrm{C}\right)$ and September $2000\left(22.6^{\circ} \mathrm{C}\right)$. The 
lowest values of dissolved oxygen were related in March (3.7mg/l) and August 2001 (3.8mg/L). The water $\mathrm{pH}$ ranged between 6.4 and 7.3 and alkalinity between 27.4 and $41.0 \mathrm{mg} / \mathrm{l}$. The highest rates of rainfall were found in February 2001 and December 2000, respectively (291.6 and $215.1 \mathrm{~mm}$ ), while the lowest value was observed in July 2001 (31.8mm) (Table 1).
The fish examined consisted of 81 males (63.3\%) and 28 females (36.7\%). The length of the hosts varied between 21.0 and $53.0 \mathrm{~cm}$ (mean length $36.5 \mathrm{~cm}$ ) and weight from 200 to 2,500g (mean weight 865.9) (Table 2). There was no relationship $(\mathrm{P}>0.05)$ between the sex of the hosts and parasitological indexes.

Table 1. Mean values of the rainfall (RF) and water quality measured in Paraná River, Presidente Epitácio, SP, between August 2000 and August 2001 during the fish collection

\begin{tabular}{cccccccc}
\hline Month & $\begin{array}{c}\text { RF } \\
(\mathrm{mm})\end{array}$ & $\begin{array}{c}\text { Transparency } \\
(\mathrm{m})\end{array}$ & $\begin{array}{c}\text { Alkalinity } \\
(\mathrm{mg} / \mathrm{l})\end{array}$ & $\mathrm{pH}$ & $\begin{array}{c}\text { Conductivity } \\
(\mu \mathrm{S} / \mathrm{cm})\end{array}$ & $\begin{array}{c}\text { Temperature } \\
\left({ }^{\circ} \mathrm{C}\right)\end{array}$ & $\begin{array}{c}\text { Oxygen } \\
(\mathrm{mg} / \mathrm{l})\end{array}$ \\
\hline Aug/2000 & 64.8 & 2.4 & 27.4 & 7.1 & 50.1 & 23.6 & 9.1 \\
Sep/2000 & 195.4 & 2.4 & 27.4 & 7.3 & 81.8 & 22.6 & 8.0 \\
Oct/2000 & 67.0 & 2.4 & 27.4 & 7.1 & 56.4 & 26.7 & 7.3 \\
Nov/2000 & 142.4 & 2.4 & 27.4 & 7.3 & 49.0 & 28.7 & 6.4 \\
Dec/2000 & 215.1 & 2.4 & 27.4 & 7.3 & 49.8 & 27.7 & 6.2 \\
Feb/2001 & 291.6 & 2.4 & 27.4 & 6.4 & 55.1 & 28.4 & 6.3 \\
Mar/2001 & 130.6 & 2.4 & 27.4 & 6.4 & 57.0 & 28.2 & 3.7 \\
Apr/2001 & 57.2 & 2.4 & 27.4 & 6.4 & 56.5 & 27.1 & 6.5 \\
May/2001 & 140.8 & 2.4 & 27.4 & 6.4 & 56.6 & 28.8 & 6.5 \\
Jun/2001 & 52.9 & 2.4 & 27.4 & 6.4 & 56.5 & 27.6 & 6.7 \\
Jul/2001 & 31.8 & 2.4 & 29.5 & 6.7 & 57.0 & 23.6 & 6.0 \\
Aug/2001 & 50.0 & 2.4 & 41.0 & 6.4 & 56.7 & 22.0 & 3.8 \\
\hline
\end{tabular}

Table 2. Parasitological indexes in Cichla sp. parasitized by proteocephalid cestodes in Paraná River, Presidente Epitácio, SP

\begin{tabular}{ccccccc}
\hline Month & Fish weight (g) & $\begin{array}{c}\text { Fish length } \\
(\mathrm{cm})\end{array}$ & CF/IF & P (\%) & MA & MI \\
\hline Aug/2000 & $1112.5(450-1725)$ & $40.3(30-47.5)$ & $8 / 5$ & 62.5 & 40.4 & $80.8(0-182)$ \\
Sep/2000 & $590(450-850)$ & $32.9(30-37)$ & $10 / 0$ & 0 & 0 & 0 \\
Out/2000 & $650(350-950)$ & $34.6(27-39)$ & $10 / 3$ & 30.0 & 16.6 & $55.33(0-102)$ \\
Nov/2000 & $805(350-950)$ & $35.4(29-45.5)$ & $10 / 7$ & 70.0 & 11.0 & $15.71(0-26)$ \\
Dec/2000 & $1100(550-2500)$ & $39.3(34-50)$ & $10 / 6$ & 60.0 & 155.5 & $259.17(0-1224)$ \\
Jan/2001 & $992.5(500-1600)$ & $39.1(33-46)$ & $10 / 8$ & 80.0 & 72.7 & $90.87(0-438)$ \\
Feb/2001 & $850(200-2500)$ & $34.0(23-50)$ & $10 / 9$ & 90.0 & 1122.4 & $1247.11(0-8301)$ \\
Mar/2001 & $935(200-1600)$ & $36.4(21-48)$ & $10 / 5$ & 50.0 & 242.5 & $485(0-1543)$ \\
Apr/2001 & $925(450-1400)$ & $38.0(30-46)$ & $10 / 8$ & 80.0 & 2.9 & $3.62(0-6)$ \\
May/2001 & $825(350-1550)$ & $36.1(27-46)$ & $10 / 5$ & 50.0 & 26.6 & $53.2(0-211)$ \\
Jun/2001 & $1271(600-2400)$ & $42.0(32.5-53)$ & $10 / 6$ & 60.0 & 4.5 & $7.5(0-14)$ \\
Jul/2001 & $585(200-1100)$ & $31.6(23-42)$ & $10 / 6$ & 60.0 & 330.4 & $550.67(0-1064)$ \\
Aug/2001 & $665(450-950)$ & $35.2(32-39)$ & $10 / 3$ & 30.0 & 16.6 & $55.33(0-102)$ \\
\hline Total & $865.9(200-2500)$ & $36.5(21-53)$ & $128 / 71$ & 55.58 & 157.08 & $223.41(0-8301)$ \\
\hline
\end{tabular}

IF/CF: infected fish/collected fish; P: prevalence; MA: mean abundance; MI: mean intensity. Range in parentheses.

The species of cestodes identified as $P$. macrophallus and $P$. microscopicus were found during the whole period, except in September 2000. The total prevalence was $55.6 \%$, with higher rates in February 2001 (90\%), followed by January and April 2001 (80\%) and the lowest rates in October 2000 and August 2001 (30\%). (Table 2)

The total mean abundance was 157.08 , with the highest index in February 2001 (1,122.4) and the lowest in April 2001 (2.9). In February 2001 the mean abundance was significantly higher than 
August $(\mathrm{P}<0.01)$, September $(\mathrm{P}<0.05)$ and October $2000(\mathrm{P}<0.05)$ and April $(\mathrm{P}<0.05)$, May $(\mathrm{P}<0.01)$ and June $2001(\mathrm{P}<0.05)$ (Table 3). On the other hand, in September 2000 the lowest mean abundance $(\mathrm{P}<0.01)$ was found when compared to July 2001 (Figure 1 and Table 3).

The mean intensity during the whole period was 223.41 and remained between 3.62 (April 2001) and 1,247.11 (February 2001). In February 2001, a significantly higher mean intensity than
November $2000(\mathrm{P}<0.01)$, April $(\mathrm{P}<0.05)$ and June $2001(\mathrm{P}<0.05)$ was observed, while April 2001 showed the lowest $(\mathrm{P}<0.05)$ value when compared to December 2000, March and July 2001 (Figure 2 and Table 3). In July 2001 the mean intensity was significantly higher than November $2000 \quad(\mathrm{P}<0.01)$ and June 2001 $(\mathrm{P}<0.05)$, while June 2001 showed significant lower mean intensity than March $2001(\mathrm{P}<0.05)$ (Table 3).

Table 3. Statistical analyses of proteocephalid cestodes in Cichla sp. from Paraná River, Presidente Epitácio, SP, from August 2000 through August 2001

\begin{tabular}{|c|c|c|c|c|c|c|c|c|c|c|c|c|}
\hline Month & $\begin{array}{l}\text { Aug/ } \\
2000 \\
\end{array}$ & $\begin{array}{l}\text { Sep/ } \\
2000 \\
\end{array}$ & $\begin{array}{c}\text { Oct/ } \\
2000 \\
\end{array}$ & $\begin{array}{l}\text { Nov/ } \\
2000 \\
\end{array}$ & $\begin{array}{l}\text { Dec/ } \\
2000 \\
\end{array}$ & $\begin{array}{l}\text { Feb/ } \\
2001 \\
\end{array}$ & $\begin{array}{l}\text { Mar/ } \\
2001 \\
\end{array}$ & $\begin{array}{l}\text { Apr/ } \\
2001 \\
\end{array}$ & $\begin{array}{l}\text { May/ } \\
2001\end{array}$ & $\begin{array}{l}\text { Jun/ } \\
2001 \\
\end{array}$ & $\begin{array}{c}\mathrm{Jul} / \\
2001 \\
\end{array}$ & $\begin{array}{l}\text { Aug/ } \\
2001 \\
\end{array}$ \\
\hline Aug 2000 & - & ns & ns & ns & ns & ns & ns & ns & ns & ns & ns & ns \\
\hline Sep 2000 & ns & - & ns & ns & ns & ns & ns & ns & ns & ns & ns & ns \\
\hline Oct 2000 & ns & ns & - & ns & ns & ns & ns & ns & ns & ns & ns & ns \\
\hline Nov 2000 & ns & ns & ns & - & ns & $*$ & ns & ns & ns & ns & * & ns \\
\hline Dec 2000 & ns & ns & ns & ns & - & ns & ns & $* *$ & ns & ns & ns & ns \\
\hline Feb 2001 & $*$ & $* *$ & ** & ns & ns & - & ns & $* *$ & ns & $* *$ & ns & ns \\
\hline Mar 2001 & ns & ns & ns & ns & ns & ns & - & $* *$ & ns & $* *$ & ns & ns \\
\hline Apr 2001 & ns & ns & ns & ns & ns & $* *$ & ns & - & ns & ns & $* *$ & ns \\
\hline May 2001 & ns & ns & ns & ns & ns & $*$ & ns & ns & - & ns & ns & ns \\
\hline Jun 2001 & ns & ns & ns & ns & ns & $* *$ & ns & ns & ns & - & $* *$ & ns \\
\hline Jul 2001 & ns & $*$ & ns & ns & ns & ns & ns & ns & ns & ns & - & ns \\
\hline Aug 2001 & ns & ns & ns & ns & ns & ns & ns & ns & ns & ns & ns & - \\
\hline
\end{tabular}

The mean intensity is above the diagonal and the mean abundance is below the diagonal. ${ }^{*} \mathrm{P}<0.01$; ${ }^{* *} \mathrm{P}<0.05$; $\mathrm{ns}$ $\mathrm{P}>0.05$

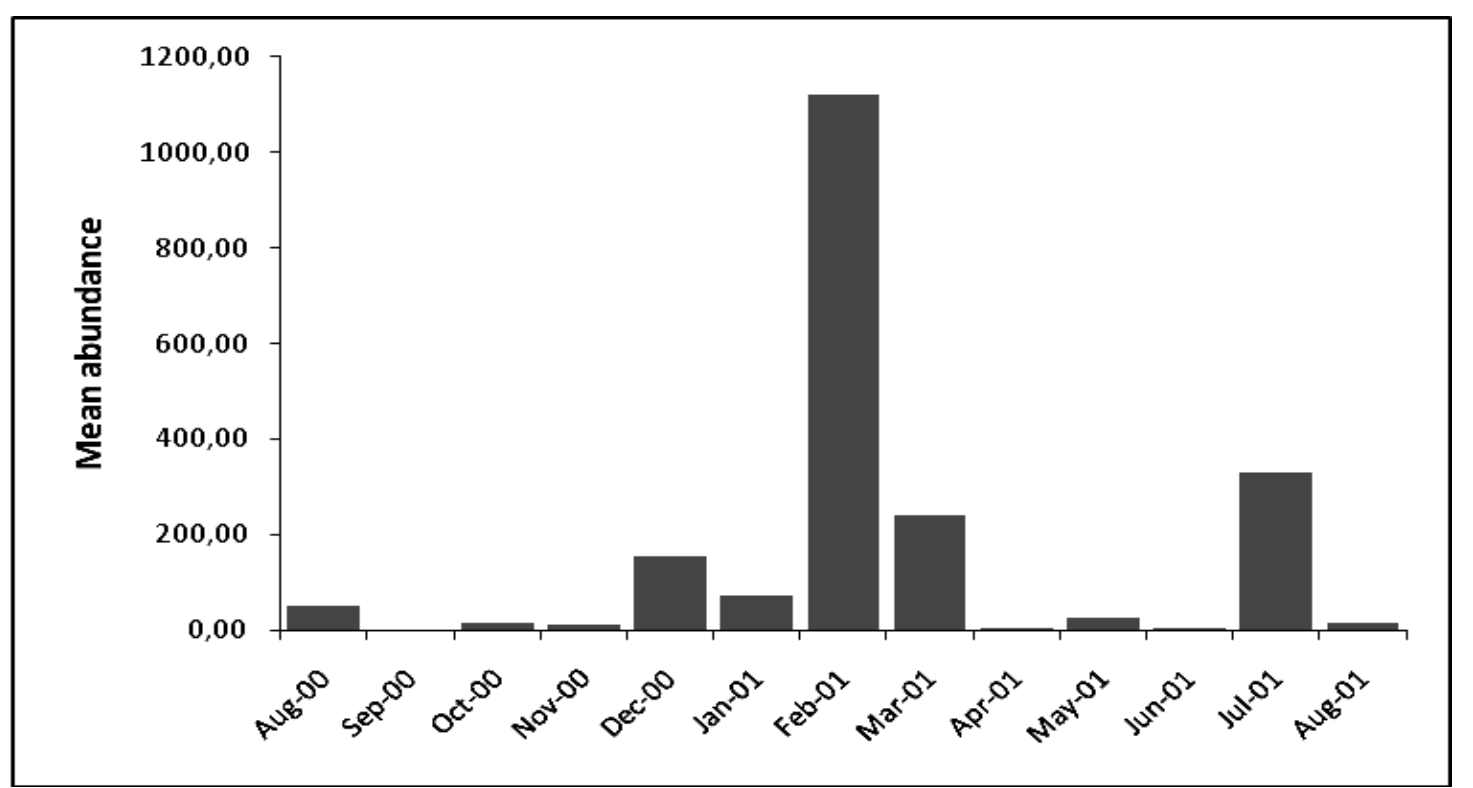

Figure 1. Mean abundance of proteocephalid cestode parasites in Cichla sp. in the Paraná River, Presidente Epitácio, SP, from August 2000 through August 2001. 


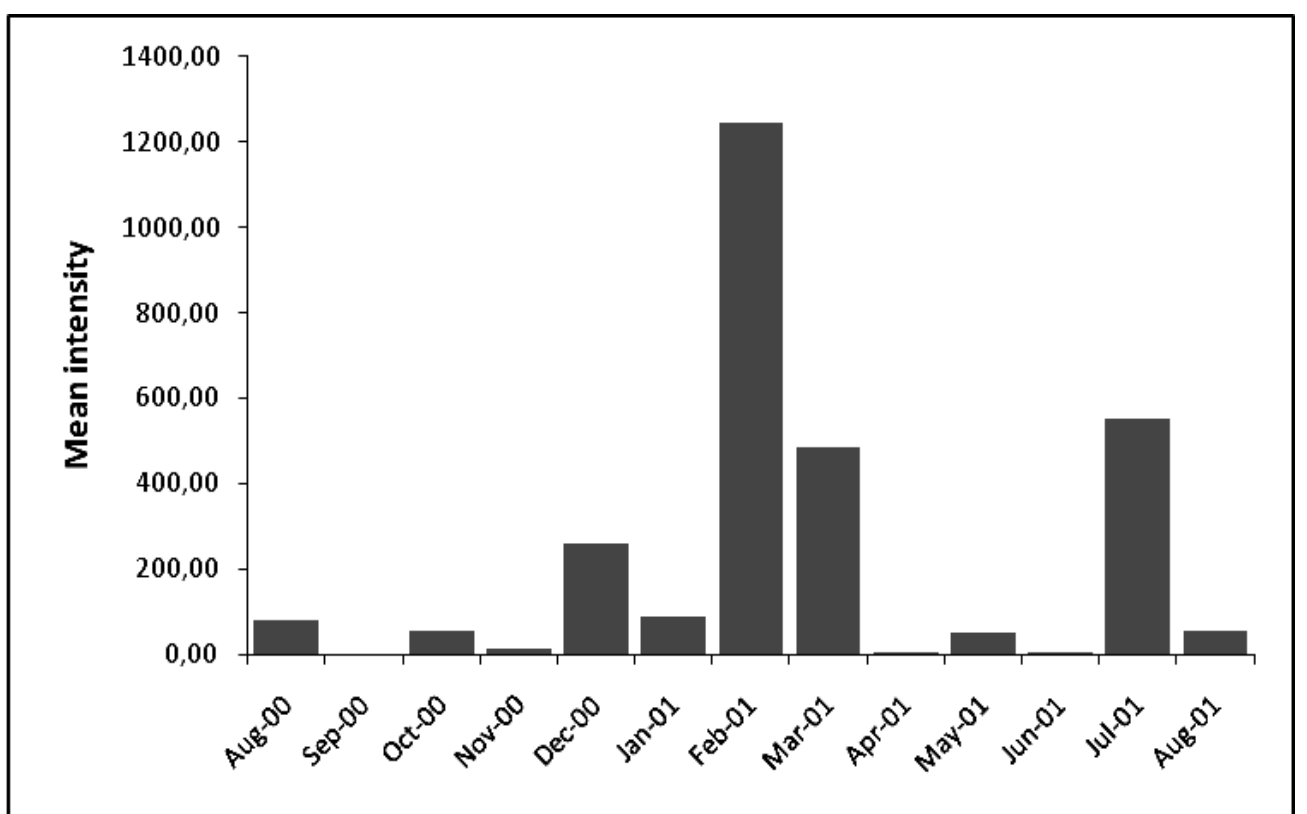

Figure 2. Mean intensity of proteocephalid cestode parasites in Cichla sp. in the Paraná river, Presidente Epitácio, SP, from August 2000 through August 2001.

\section{DISCUSSION}

It can be inferred that the highest mean abundance in December 2000, January, February and March 2001 were related to the rainfall values. But the unexplained fact was the isolated high mean abundance in July 2001. Such as observed by Martins et al. (2009) in a reservoir environment, this study cannot confirm this fact. These authors found that $100 \%$ prevalence and high mean intensity coincided with the highest biomass algae. This fact can be explained by the fact that a river is a very dynamic environment, very different from reservoirs.

Rego et al. (1999) referred 80 species of proteocephalid cestodes from freshwater fish in South America, most of them found in Siluriform fish. Proteocephalid cestodes constitute the most numerous and important helminthes of freshwater fish. These authors argued that the large concentration of proteocephalid genera occurs in South America, but the greatest species concentration, especially of the primitive genus Proteocephalus Weiwlawdi 1858 occurs in Eurasia and North America.

Proteocephalus macrophalus and $P$. microscopicus appear to be exclusive to the tucunaré, and have never been recorded in other species (Rego, 1994). Other studies with alien fish Cichla sp. in Brazil identified the same species found in this work: Cichla monoculus in Paraná River, Paraná (Machado et al., 2000) and Cichla piquiti, in Volta Grande Reservoir, Minas Gerais (Martins et al., 2009). In both studies, the total prevalence rates were higher than that related in the present study, which were $83.3 \%$ and $97 \%$, respectively.

In terms of total prevalence, in Paraná River four species of proteocephalid cestodes in Sorubim lima were found with higher prevalence rate (88.8\%) than the present study and lower mean intensity (79.71 parasites per host) (Takemoto and Pavanelli, 2000). Similar proteocephalid prevalence rates during the whole studied period were also observed by these authors who have studied proteocephalid in another region of the Paraná River. De Chambrier and Rego (1994), Machado et al. (1994) and de Chambrier (2003) have found lower prevalence rates and mean intensities of proteocephalids in Pseudoplatystoma corruscans, P. luetkeni and Sorubim lima, respectively.

The feeding habit of tucunaré includes several species of fish that could act as intermediate or paratenic hosts for these parasites (Machado et al., 2000). Furthermore, Gomiero and Braga (2004b) reported high rates of cannibalism in Cichla cf. ocellaris and C. monoculus, which 
suggests a possible transmission of the cestodes by ingestion. Thomas et al. (2002) focused on the parasite strategies that can lead to their successful life or not. In fact, one of the strategies of Cichla sp. could be its feeding behavior constituted by small infected fish.

Parental care and predatory behavior are two ecological characteristics of the alien species, as tucunaré. The parental care may increase the competitiveness of these species and the predatory behavior put the alien fish on the top of the food web (Latini and Petrere Jr., 2004) which may explain the high number of parasites observed in this study.

In most of months the mean abundance was lower than that related by Martins et al. (2009). In fact, it must be emphasized that the reservoirs may play an important role on parasite dissemination especially to piscivorous fish that are on the top of the food web.

In the present work, no relationship between parasitological indexes and the sex of the hosts may be evidence that males and females have similar diets and feeding habits in agreement with the findings of Muzzal (1980) and Takemoto and Pavanelli (1994).

\section{ACKNOWLEDGEMENTS}

The authors thank CNPq (National Council of Scientific and Technological Development) for the grant to M.L. Martins and Dr. Alain De Chambrier for parasite identification.

\section{REFERENCES}

BUSH, A.O.; LAFFERTY, K.D.; LOTZ, J. et al. Parasitology meets ecology on its own terms: Margolis et al. revisited. J. Parasitol., v.83, p.575583, 1997.

de CHAMBRIER, A. Systematic status of Manaosia bracodemoca Woodland, 1935 and Paramonticellia itaipuensis Pavanelli et Rego, 1991 (Eucestoda: Proteocephalidea), parasites of Sorubim lima (Siluriformes: Pimelodidae) from South America. Folia Parasitol., v.50, p.121-127, 2003. de CHAMBRIER, A.; REGO, A.A. Proteocephalus sophiae n. sp. (Cestoda: Proteocephalidae), a parasite of the siluroid fish Paulicea luetkeni (Pisces: Pimelodidae) from the Brazilian Amazon. Rev. Suisse Zool., v.101, p. 361-368, 1994.

de CHAMBRIER, A.A.; PERTIERRA, A.A.G. Redescription of Travassiella avitellina Rego and Pavanelli, 1987 (Proteocephalidea: Monticelliidae, Zygobothriinae), a parasite of Paulicea luetkeni (Siluriformes) from South América. Mem. Inst. Oswaldo Cruz, v.97, p.657-661, 2002.

de CHAMBRIER, A.; REGO, A.A.; VAUCHER, C. Euzetiella tetraphylliformis n. gen. n. sp. (Eucestoda: Proteocephalidae), parasite du poisson d'eau douce néotropical Paulicea luetkeni (Siluriforme, Pimelodidae). Parasite, v.6, p.43-47, 1999.

de CHAMBRIER, A.; TAKEMOTO, R.M.; PAVANELLI, G.C. Nomimoscolex pertierrae n. sp. (Eucestoda: Proteocephalidea), a parasite of Pseudoplatystoma corruscans (Siluriforme: Pimelodidae) in Brazil and redescription of Nomimoscolex sudobim Woodland, 1935, a parasite of P. fasciatum. Syst. Parasitol., v.64, p.191-202, 2006.

DOGIEL, V.A. Ecology of the parasites of freshwater fishes. In: DOGIEL, V.A.; PETRUSHEVSKI, G.K.; POLYANSKI, Y.I. (Eds.). Parasitology of fishes. Hong Kong: TFH Publications, 1970. p.1-47.

GOMIERO, L.M.; BRAGA, F.M.S. Relação pesocomprimento e fator de condição para Cichla cf. ocellaris e Cichla monoculus (Perciformes, Cichlidae) no reservatório de Volta Grande, rio Grande - MG/SP. Acta Sci. Biol. Sci., v.25, p.79-86, 2003.

GOMIERO, L.M.; BRAGA, F.M.S. Cannibalism as the feeding behaviour of Tucunarés introduced in Southeast Brazil. Braz. J. Biol., v.64, p.625-632, 2004a.

GOMIERO, L.M.; BRAGA, F.M.S. Reproduction of species of the genus Cichla in a reservoir in Southeastern Brazil. Braz. J. Biol., v.64, p.613-624, 2004b.

JEPSEN, D.B.; WINEMILLER, K.O.; TAPHORN, D.C. Temporal patterns of resource partitioning among Cichla species in a Venezuelan blackwater river. J. Fish Biol., v.51, p.1085-1108, 1997.

LANGERON, M. Précis de microscopie. 7.ed. Paris: Masson and Cie, 1949. 1429 p. 
LATINI, A.O.; PETRERE Jr., M. Reduction of a native fish fauna by alien species: an example from Brazilian freshwater tropical lakes. Fish Manag. Ecol., v.11, p.71-79, 2004.

MACHADO, M.H.; PAVANELLI, G.C.; TAKEMOTO, R.M. Influence of host's sex and size on endoparasitic infrapopulations of Pseudoplatystoma corruscans and Schizodon borelli (Osteichthyes) of the High Paraná River, Brazil. Rev. Bras. Parasitol. Vet., v.3, p.143-148, 1994.

MACHADO, P.M.; ALMEIDA, S.C.; PAVANELLI, G.C. et al. Ecological aspects of endohelminths parasitizing Cichla monoculus Spix, 1831 (Perciformes: Cichlidae) in the Paraná River near Porto Rico, State of Paraná, Brazil. Comp. Parasitol., v.67, p.210-217, 2000.

MARTINS, M.L.; PEREIRA Jr., J. de CHAMBRIER, A. et al. Proteocephalid cestode infection in alien fish, Cichla piquiti Kullander and Ferreira, 2006 (Osteichthyes: Cichlidae), from Volta Grande reservoir, Minas Gerais, Brasil. Braz. J. Biol., v.69, p.189-195, 2009.

MUZZAL, P.M. Population biology and hostparasite relationships of Triganodistomum attenuatum (Trematoda: Lissorchiidae) infecting the white sucker, Catostomus commersoni (Lacépède). J. Parasitol., v.66, p.293-298, 1980.

PAVANELLI, G.C.; SANTOS, M.HM. Cangatiella arandasi gen. sp. n. (Cestoda: Proteocephalidae) parasito de Parauchenipterus galeatus (Siluriformes: Auchnipteridae) do rio Paraná. Rev. Bras. Zool., v.7, p.535-539, 1990.

PAVANELLI, G.C.; SANTOS, M.H.M. Proteocefalídeos parasitos de peixes, em especial pimelodídeos do rio Paraná, Paraná. Rev. Unimar, v.13, p.147-162, 1991.

PAVANELLI, G.C.; TAKEMOTO, R.M. Aspects of the ecology of proteocephalid cestodes, parasites of Sorubim lima (Pimelodidae) of the upper Paraná River, Brazil: II. Interspecific associations and distribution of gastrointestinal parasites. Braz. J. Biol., v.60, p.585-590, 2000.
REGO, A.A. Order Proteocephalidae Mola, 1928 p. 257-293. In: KHALIL, L.F.; JONES, A.; BRAY R.A. (Eds). Keys to the cestode parasites of vertebrates. St Albans: CAB International, 1994. $751 \mathrm{p}$.

REGO, A.A. Current state of knowledge of cestodes from Neotropical freshwater fishes and rays. Rev. Bras. Zoocienc., v.6, p.61-79, 2004.

REGO, A.A.; CHUBB, J.C.; PAVANELLI, G.C. Cestodes in South American freshwater teleost fishes: keys to genera and brief description of species. Rev. Bras. Zool., v.16, p.299-367, 1999.

REGO, A.A.; de CHAMBRIER, A.; HANZELOVÁ, V. et al. Preliminary phylogenetic analysis of subfamilies of the Proteocephalidea (Eucestoda). Results of the round table of the Proteocephalidea group. In: INTERNATIONAL WORKSHOP FOR TAPEWORMS SYSTEMATICS, 2., 1996, Lincoln, Nebr. Syst. Parasitol., v.40, p.1-19, 1998.

TAKEMOTO, R.M.; PAVANELLI, G.C. Ecological aspects of proteocephalidean cestodes parasites of Paulicea luetkeni (Steindachner) (Osteichthyes: Pimelodidae) from de Paraná River, Paraná, Brasil. Rev. Unimar, v.16, p.1726, 1994.

TAKEMOTO, R.M.; PAVANELLI, G.C. Proteocephalidean cestodes in the freshwater fish Cichla monoculus from the Paraná river, Brazil. Stud. Neotrop. Fauna Environ., v.31, p.123-127, 1996.

TAKEMOTO, R.M.; PAVANELLI, G.C. Aspects of the ecology of proteocephalid cestodes parasites of Sorubim lima (Pimelodidae) of the upper Paraná river, Brazil. I. Structure and influence of host's size and sex. Braz. J. Biol., v.60, p.577-584, 2000.

THOMAS, F.; BROWN, S.P.; SUKHDEO, M. et al. Understanding parasite strategies: a statedependent approach? Trends Parasitol., v.18, p.387-390, 2002.

ZARET, T.M. The stability/diversity controversy: a test of hypotheses. Ecology, v.63, p.721-731, 1982. 